Dokuz Eylül Üniversitesi-Mühendislik Fakültesi

Fen ve Mühendislik Dergisi

Cilt 19 Sayı 55 Ocak 2017
Dokuz Eylul University-Faculty of Engineering Journal of Science and Engineering Volume 19 Issue 55 January 2017

DOI: $10.21205 /$ deufmd. 2017195507

\title{
Investigation of Single Section Part Fabrication in Shipbuilding by Utilizing Simulation Environment
}

\author{
Murat Özkök \\ Karadeniz Teknik Üniversitesi, Sürmene Deniz Bilimleri Fakültesi, Gemi İnşaatı ve \\ Gemi Makinaları Mühendisliği Bölümü, TRABZON
}

(Alınış / Received: 16.03.2016, Kabul / Accepted: 26.07.2016, Online Yayınlanma / Published Online: 09.01.2017)

$\begin{array}{ll}\text { Keywords } & \text { Abstract: Profile preparing process is an important work unit at a } \\ & \text { shipyard. At this station, the specific dimensioned profiles are } \\ \text { obtained. In the case of any delay in this work unit, the delivery } \\ \text { Shipbuilding, } & \text { date may be postponed. In order to preclude these problems, the } \\ \text { Profile, } & \text { profile work unit performance has to be satisfactory. In this study, } \\ \text { Performance } & \text { a profile processing work unit of a Turkish Shipyard was } \\ \text { analysis, } & \text { considered and the performance analysis was performed by using } \\ \text { Simulation. } & \text { a simulation software. At the first stage of the study, process } \\ & \text { analysis of the profile processing work unit was carried out and } \\ & \text { then the simulation model was created. After that, some scenarios } \\ & \text { were implemented. It was concluded from these scenarios that the } \\ & \text { improvements on the operation time of marking-cutting activities } \\ & \text { increase the production quantity of profile. On the other hand, the } \\ \text { improvements on edge sweeping and grinding activities have a } \\ \text { very little affect on throughput of profile cutting work unit. }\end{array}$

\section{Gemi İnşaatında Simülasyon Ortamı Kullanarak Tekil Profil İmalatının İncelenmesi}

\begin{tabular}{ll}
\hline Anahtar & Özet: Profil hazırlama, tersanedeki en önemli işlemlerden biridir. \\
Kelimeler & Profil işleme ünitesinde belirli boyutlara sahip profiller \\
& hazırlanmaktadır. Bu ünitede gecikme olduğunda, geminin teslim \\
Tersane, & tarihi de gecikebilmektedir. Bu tip problemleri önlemek için profil \\
Gemi inşaatı, & işleme ünitesinin performansının yeterli olması gerekmektedir. \\
Profil, & Bu çalıșmada bir tersanenin profil kesim ünitesi ele alınmış ve bu \\
Performans & ünitenin performans analizi yapılmıştır. Çalışmanın ilk kısmında, \\
analizi, & profil işleme ünitesinin süreç analizi yapılmış ve simülasyon \\
Simülasyon. & modeli oluşturulmuştur. Sonrasında, birtakım senaryolar \\
& uygulanarak çeşitli sonuçlar elde edilmiş ve değerlendirilmiştir. \\
& Bu senaryolar değerlendirildiğinde, markalama-kesim aktiviteleri \\
& üzerinde yapılabilecek olan iyileştirmelerin profil üretim \\
& miktarını artırdığı, diğer taraftan kenar temizleme ve taşlama \\
& işlemleri üzerinde yapılacak olan iyileştirmelerin profil kesim iş \\
& ünitesinin çıtı miktarını çok az etkilediği görülmüştür.
\end{tabular}




\section{Introduction}

Profiles are the parts which are frequently used in ship building. The profiles that have standart dimensions come to profile stock area located in front of profile cutting work unit at shipyards. These profiles which have standart dimensions are cut by plasma machine and the profiles having certain sizes are obtained. Afterwards, these specific dimensioned profiles are mounted to flat plates or bended plates so minor and major sub assembly structures are fabricated.

When the standart-dimensioned profiles arrive to profile cutting work unit, they are firstly subject to edge-sweeping activity that is performed to remove the primer from edges of profiles. The welding quality becomes higher by sweeping the edges. After the profile edges are being swept and the primer is removed, the profiles are transferred to marking and cutting unit. In this unit, the standart-dimensioned profiles are automatically marked in order to define the number of profiles and then are automatically cut and specific dimensioned profiles are fabricated.

The above-mentioned profile cutting activities such as edge sweeping, marking and cutting, and grinding must be completed as soon as possible in order to finish the ship production in time. If these activities are completed in a short time, the ship can be delivered in a specified time.

Most real world engineering, physical, social and economic systems are complex and stochastic [1]. Some parameters may affect the production quantity of these real systems such as activity processing time, queue time, idle time, part numbers waiting in queue etc and it is difficult to model such a complex system including various parameters. Breakthroughs in ob-ject-oriented technology provide significantly improved modeling flexibility and allow accurate modeling of highly complex system [2]. One of these breakthroughs is simulation software. To be able to see the effects of these parameters on production system, simulation software tool must be utilized. Simulation is used in order to model the current situation of production systems and determine the effects of alterations. When determining effects of a machine, for instance, that is thought to be purchased, simulation software can be used. When this is done, the effects of the machine are able to be defined and more accurate decisions can be made. Without using simulation software, it is impossible to see the effects of the changes on production system, economic losses and the trial and errors in design process become inevitable [3]. That's why, the simulation usage is very significant. The shipbuilding simulation model is able to be used to analyze the impact of new workloads, evaluate production scenarios, and idendify resource problems [4].

To be able to model shipbuilding production system, a flow analysis must be performed prior to building simulation. Flow analysis includes the definition of the work activities and also their durations and vehicles used. After defining work activities and determining their durations, they need to be modeled on a simulation software.

In literature, there are various simulation studies. Shin et al [5] modeled a subassembly line at a shipyard by using simu-lation tool and determine the effects of variations in resource performance such as a new welding robot and the number of workers. Kim et al [6] proposed a shipyard simulation 
model that can simulate the crane operation and block erection. In their research, they determined the effects of different block erection methods on total erection time. Lee et al [7] presented a production execution planning system for panel block operations using simulation tool and this system was also used to optimise the scheduling to make better decisions. Shin et al [8] created a framework suggesting how to achieve a efficient shipyard layout desgin and the authors measured the performance of shipyard layouts by using a computer simulation. Yasuhisa and Kentaro [9] has taken up the pipe unit assembly in a shipyard as an example and developed the assembly simulation program of the pipe units and they applied the computer simulation in a pipe shop to check the purchased parts and to allot them to the pallets. Cheng and Feng [10] presented a new mechanism that integrates simulation with Genetic Algorithm (GA) to find the best resource combination including work power and cranes for sewer pipeline installation process. Shin and Sohn [11] designed an automated fabrication workshop consisting of cutting, rolling, and line heating by utilizing simulation and they evaluated the overall performance of the system, such as waiting time for processingidle time for machinery, and rapid completion time. Cha and Roh [12] created a simulation model that simulated the block erection process and they determined the delay time in the queue of the entities in order to evaluate the performance. Woo et al [13] presented a simulation model of the transportation activities at shipyard in order to improve plans on logistics operation and evaluated the effects of the changes of the shipyard layout. Song et al [14] performed a simulation research including shipyard layout optimization, load balancing, activity planning, and block logictics and they integrated each item into a network system in order to make a decision on operation process. Lee et al [15] simulated the whole production system of a shipyard in order to evaluate work plan and applied some scenarios to see the effects of the changes on the model and attempted to create integrated system at shipyard. Kolich et al [16] performed a simulation model of an actual shipyard's panel-block assembly facilities and applied lean manufacturing methodology in order to improve the flow of interim products at shipyard.

In this study, a profile cutting work unit of a Turkish Shipyard was selected as an example. By defining the work flow of profile cutting work unit, the simulation model was created in SIMIO software simulation environment. Then, three scenarios namely Scenario A, B, and C were applied on simulation model and the effects of altering processing times of activities on profile production quantity were determined.

\section{Material and Method}

In this study, SIMIO simulation software was utilized so as to model the profile cutting work unit of a shipyard located in Turkey. This study consists of four phases and these phases are depicted in Figure 1.

In Step 1, the work flow of profile cutting work unit was identified. In this step, the processing times of the activities, loading, unloading times, and speed of vehicles, distances between work units were determined. In Step 2, the simulation model of profile cutting work unit was created by using SIMIO simulation software. In the model, various modules belonging to SIMIO are available and the data achieving from work flow analysis were inserted in modules. 

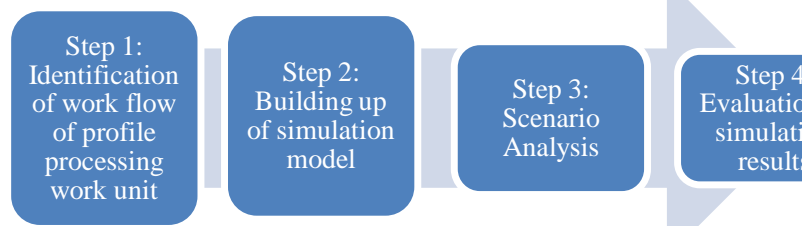

Evaluation of

simulation

Figure 1. Main stages of the study

Therefore, the simulation model was completed. In Step 3, number of three scenarios were applied on simulation model and defined the effects of these scenarios on production quantity of profile cutting work unit. In the final stage (Step 4), the results obtaining from simulation were evaluated.

\section{Implementation}

This section consists of 4 parts. In the first part, the work flow of profile cutting work unit was identified. In the second part, the simulation model of work unit was built up. After that, the scenario analysis was performed in the thirt part. And finally, in the fourth part, the evaluation of simulation result were presented.

\subsection{Identification of work flow of profile cutting work unit}

There are number of 8 processes performed in profile cutting work unit and the work flow is represented in Figure 2. Accordingly, number of 5 transportation activities are available in work flow. Besides, there are 3 fabrication activities in profile cutting work unit.

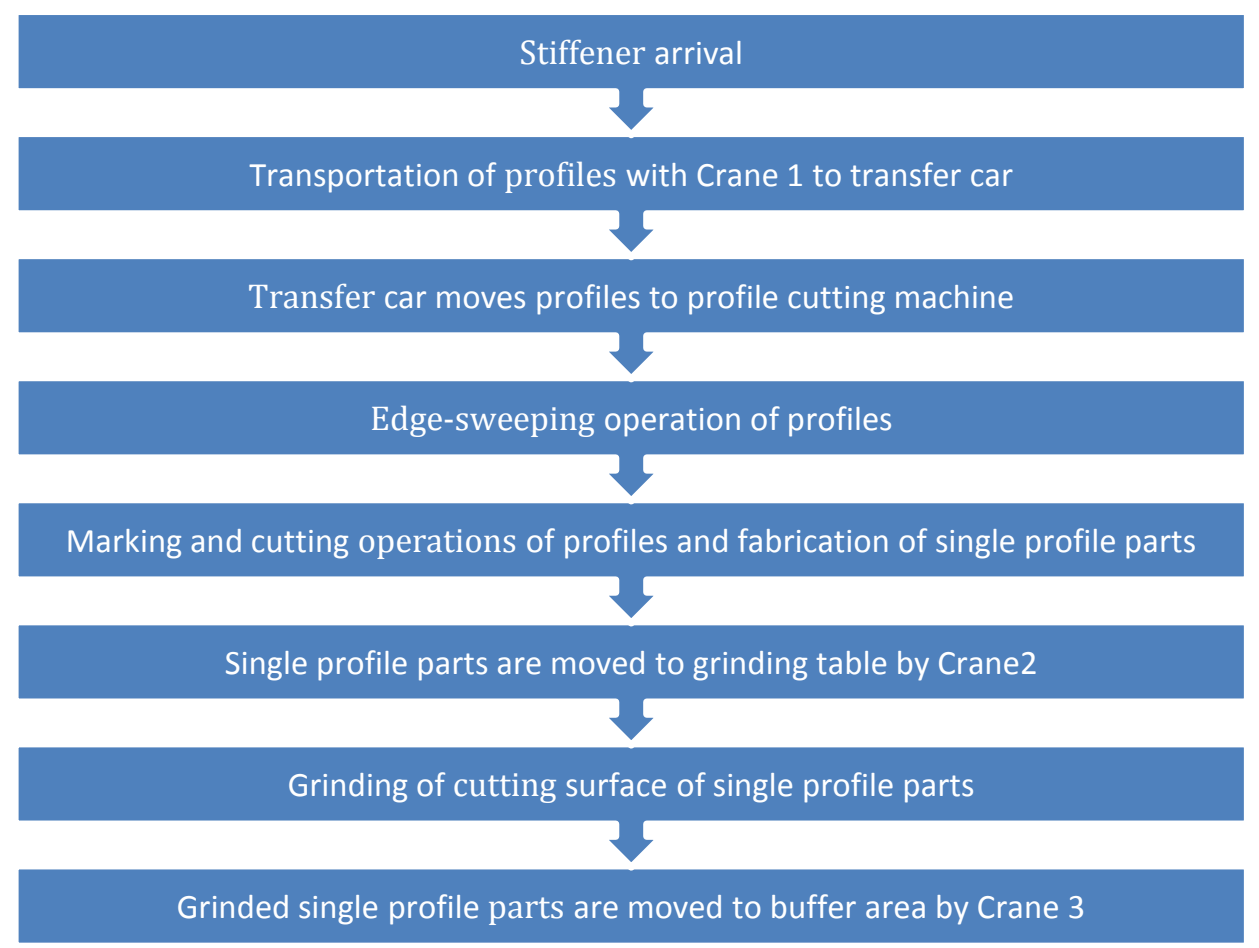

Figure 2. Work flow of profile processing work unit 


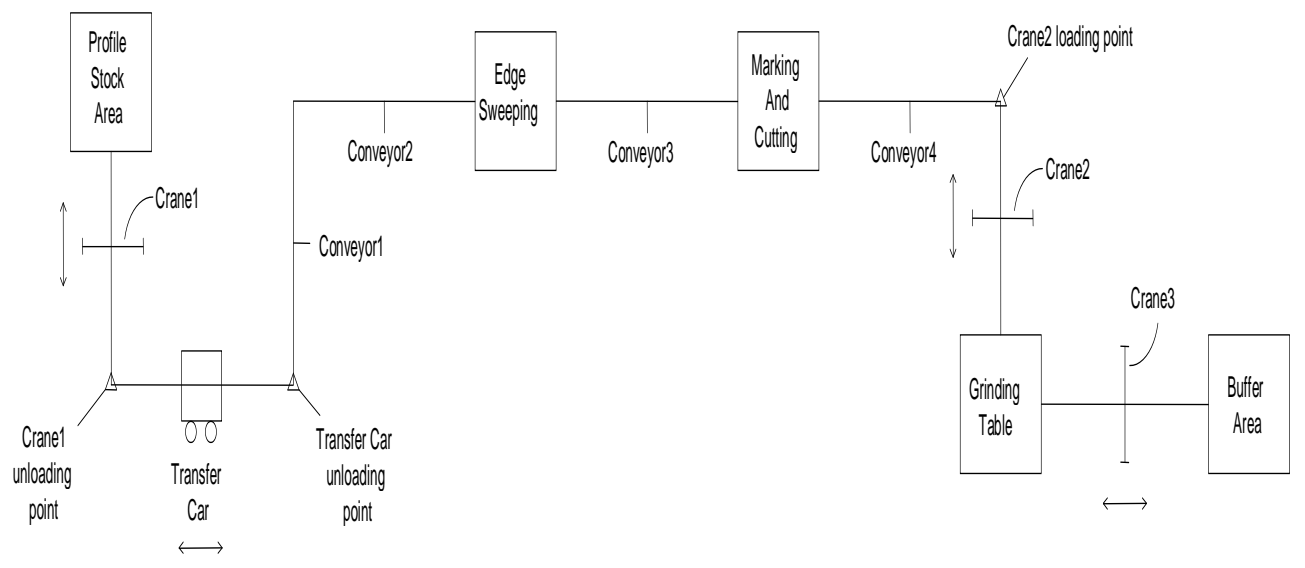

Figure 3. General view of profile processing work unit

In the work flow analysis of profile processing work unit, distances between the points, speed of the vehicles used, and processing times of the work activities were also defined. Table 1 shows the distances in meters between the points. In the model, three cranes and a transfer car and conveyors were used as transportation vehicles. Table 2 presents the speed, loading, and unloading times of the vehicles. In profile cutting work unit, there are three types of processing such as edge-grinding, marking and cut, and grinding Table 3 depicts the processing times of the work activities. As can be seen from Table 3, Edge Grinding, Marking and Cutting, and Grinding activities last 2, 6, and 1 minutes, respectively.

Table 1. Distances between points in profile cutting work unit

\begin{tabular}{|l|l|l|}
\hline From & To & Distance (m) \\
\hline Profile stock area & Crane1 unloading point & 4 \\
\hline Crane1 unloading point & Transfer car unloading point & 10.5 \\
\hline Conveyor 1's start & Conveyor 1's finish & 8 \\
\hline Conveyor 2's start & Conveyor 2's finish & 4 \\
\hline Conveyor 3's start & Conveyor 3's finish & 6 \\
\hline Conveyor 4's start & Conveyor 4's finish & 10 \\
\hline Crane 2 loading point & Grinding table & 6 \\
\hline Grinding table & Buffer area & 8 \\
\hline
\end{tabular}

Table 2. Speed-load-unload values of vehicles in simulation model

\begin{tabular}{|l|l|l|l|}
\hline Vehicle name & $\begin{array}{l}\text { Vehicle speed } \\
\text { (meters per min) }\end{array}$ & $\begin{array}{l}\text { Loading time } \\
\text { (min.) }\end{array}$ & $\begin{array}{l}\text { Unloading time } \\
\text { (min.) }\end{array}$ \\
\hline Crane1 & 20 & 1 & 0,75 \\
\hline Crane2 & 20 & 1 & 0,75 \\
\hline Crane3 & 20 & 1 & 0,75 \\
\hline Transfer car & 17.5 & - & 0.48 \\
\hline Conveyor & 15 & - & - \\
\hline
\end{tabular}


Table 3. Processing times of activities

\begin{tabular}{|l|l|}
\hline Processing type & Processing time (minutes) \\
\hline Edge grinding & 2 \\
\hline Marking and Cutting & 6 \\
\hline Grinding & 1 \\
\hline
\end{tabular}

In the simulation model, it was also assumed that some failures occurred while performing edge-sweeping and marking-cutting operations. Table 4 shows the uptime between failures and time to repair values. Accordingly, in edge-sweeping operation, a failure per 7 days happens and the repair time lasts 2 hours. The same things are valid for marking-cutting and grinding activities. It was also assumed that cranes and transfer cars failure per 7 days and repair period lasts 3 hours.

Table 4. Failures and time to repair

\begin{tabular}{|l|l|l|}
\hline Failure region & $\begin{array}{l}\text { Uptime between } \\
\text { failures (days) }\end{array}$ & $\begin{array}{l}\text { Time to repair } \\
\text { (hours) }\end{array}$ \\
\hline Edge-sweeping & 7 & 2 \\
\hline Marking-cutting & 7 & 2 \\
\hline Grinding & 7 & 2 \\
\hline Crane1 & 7 & 3 \\
\hline Crane2 & 7 & 3 \\
\hline Crane3 & 7 & 3 \\
\hline Transfer car & 7 & 3 \\
\hline
\end{tabular}

\subsection{Building of simulation model for stiffener cutting work unit}

In this stage, simulation model of profile cutting work unit was builded up by using SIMIO simulation environment. Figure 4 shows the simulation model of work cutting work unit in SIMIO environment. Standart-dimensioned profiles are carried by Crane 1 from Source 1 to Transfer car. Transfer car transfers to Conveyor that carries profiles to Edge Grinding unit. After the profiles are edge-grinded, they are transferred to Marking and Cut unit where single profile parts are fabricated. Then, Crane 2 transports the single profile parts to Grinding unit where they are grinded. After the single profile parts are grinded, they are transferred to buffer area by Crane3.

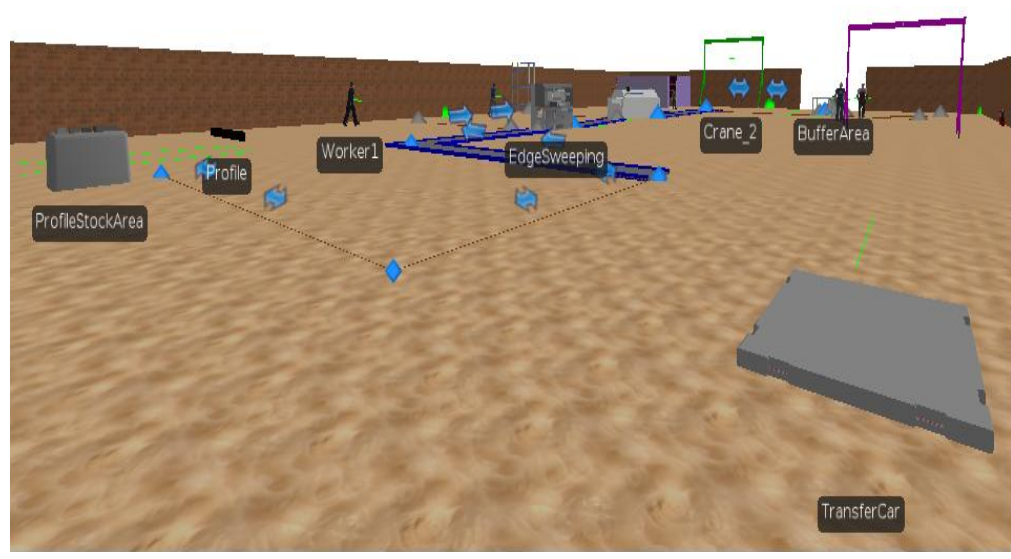

Figure 4. Simulation model of stiffener cutting work unit 
M. Özkök / Investigation of Single Section Part Fabrication in Shipbuilding by Utilizing Simulation Environment

In the model, some processes were created in order for simulation model to operate more effectively. Figures 5, 6, and 7 depict the processes in simulation environment.

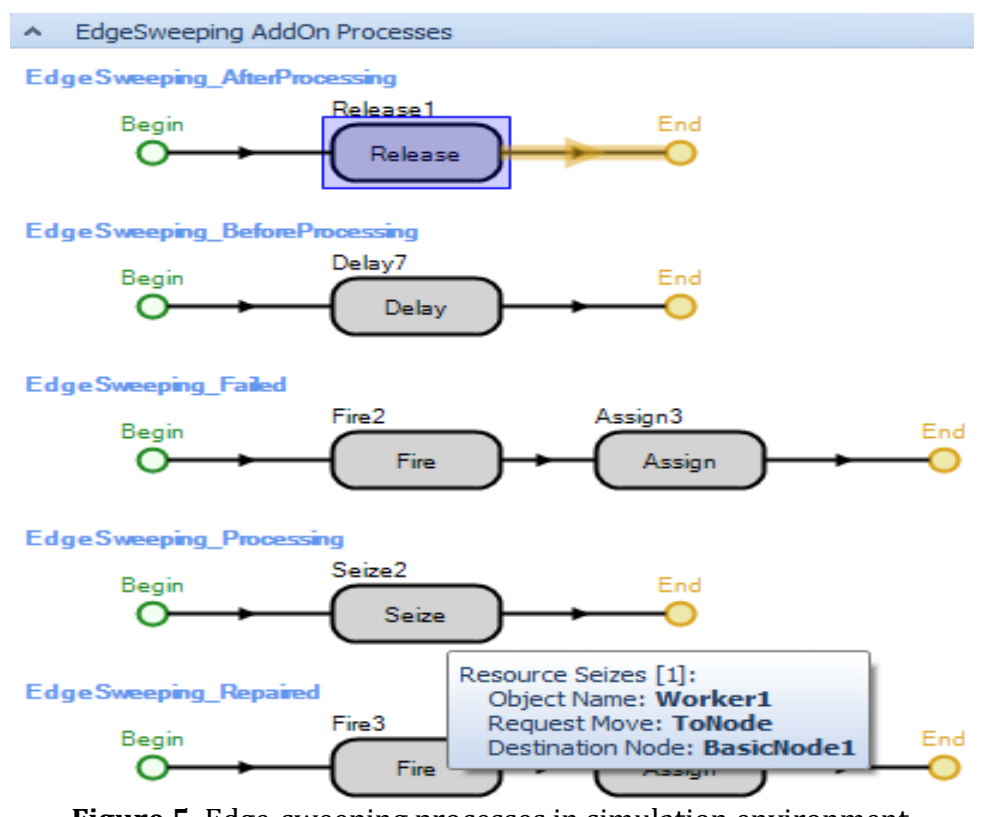

Figure 5. Edge-sweeping processes in simulation environment

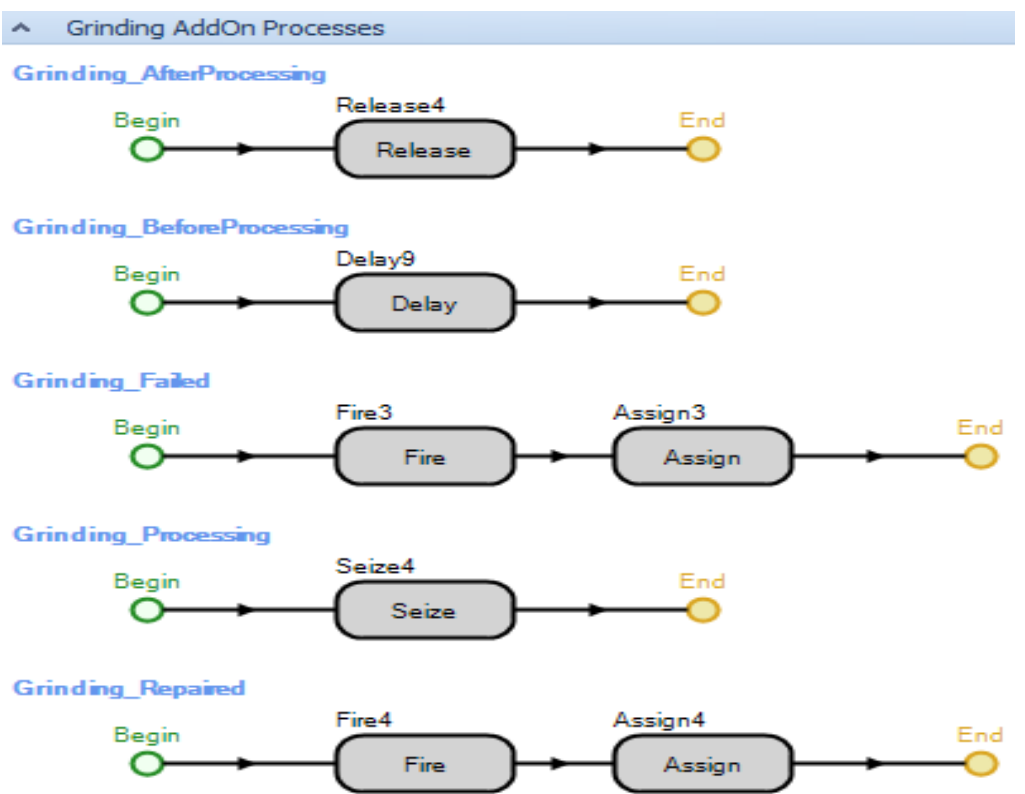

Figure 6. Grinding processes in simulation environment 


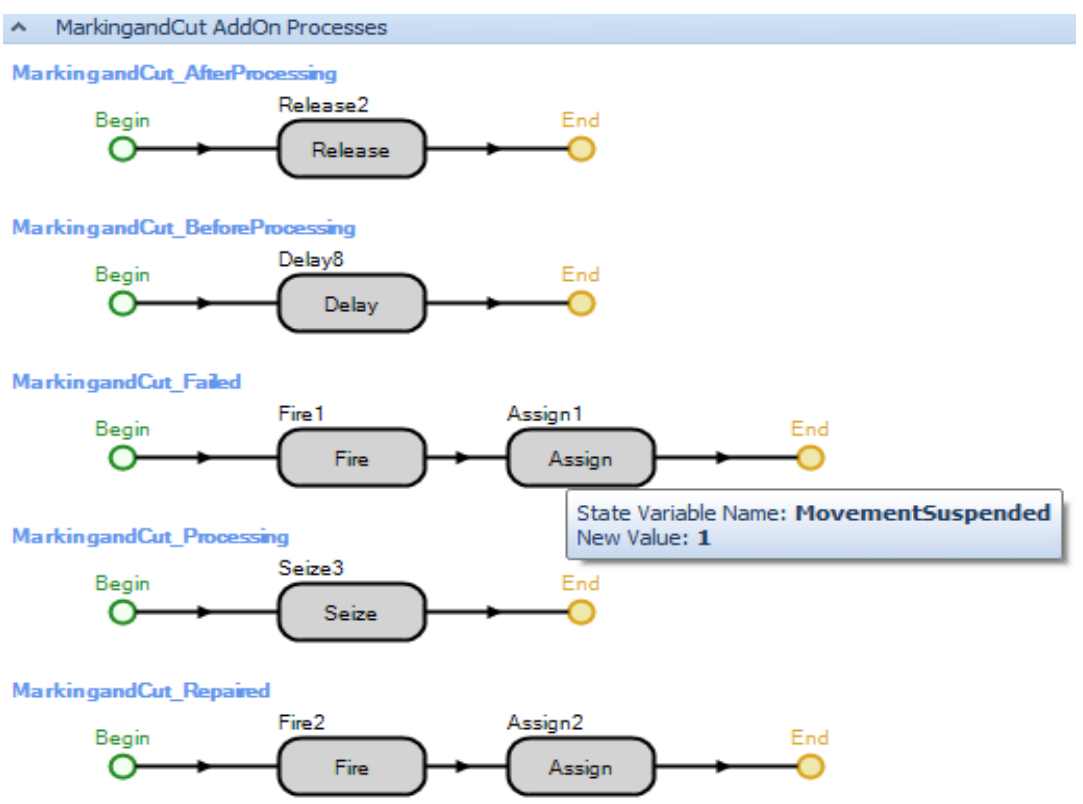

Figure 7. Marking-cutting processes in simulation environment

\subsection{Scenario analysis}

In this step, some scenarios as Scenario A, B, and C were applied on simulation model.

Scenario A analysis: In this case, while the operation time of edge sweeping activity is reducing, the operation times of marking-cutting and grinding activities remain constant. Figures 8 and 9 show the simulation result for Scenario A. In this scenario, operation time of edge sweeping activity is reducing from 2 minutes to 1.2 minutes.
By doing this, it is aimed to determine the effects of alteration of operation time for edge cutting activity on production quantity. While reducing the time of edge sweeping activitiy, five subscenarios are emerged. In Scenario 1, for instance, while the operation time for edge sweeping activity is 2 minutes, the operation times for marking-cutting activities and grinding activity are 6 and 1 minutes, respectively. The definitions of other scenarios (from Scenario 2 to Scenario 5) can be seen from Figure 8.

\begin{tabular}{|c|c|c|c|c|c|c|c|c|c|c|c|}
\hline & & & & & I & & Starting Time: & 7.7.2014 08:00:00 & - & $\theta$ & (10) Selected: \\
\hline & Cancel & Reset & Add Respons & $\begin{array}{l}\text { Remove } \\
\text { Response }\end{array}$ & Add Constraint & $\begin{array}{l}\text { Remove } \\
\text { Constraint }\end{array}$ & Ending Type: & 7.8.2014 17:00:00 & - & $\begin{array}{l}\text { Subset } \\
\text { Selection }\end{array}$ & $\begin{array}{c}\text { Select } \\
\text { Add-In }\end{array}$ \\
\hline & & & & eriment & & & & Run Setup & & Analysis & Add-Ins \\
\hline & Design $\triangle$ & Response & Se Results & Pivot Grid & Reports & & & & & & \\
\hline & Scenario & & Replications & & Controls & & & & & & Responses \\
\hline & $\begin{array}{ll}\nabla & \text { Name }\end{array}$ & Status & Required & Completed & ProcessingTime_E & EdgeSweeping & ProcessingTin & ne__MarkingandCutting & Proce & ngTime_Grinding & ProductionQuantity \\
\hline 1 & 7) Scenario1 & Completed & $d$ & 20 of 20 & 2 & & 6 & & 1 & & 5105 \\
\hline & (V) Scenario2 & Completed & d & 20 of 20 & 1.8 & & 6 & & 1 & & 5106 \\
\hline & (1) Scenario3 & Completed & d & 20 of 20 & 1.6 & & 6 & & 1 & & 5106 \\
\hline & V) Scenario4 & Completed & d & 20 of 20 & 1.4 & & 6 & & 1 & & 5108 \\
\hline & (7) Scenario5 & Completed & d & 20 of 20 & 1.2 & & 6 & & 1 & & 5108 \\
\hline
\end{tabular}

Figure 8. Simulation results based on Scenario A 
M. Özkök / Investigation of Single Section Part Fabrication in Shipbuilding by Utilizing Simulation Environment

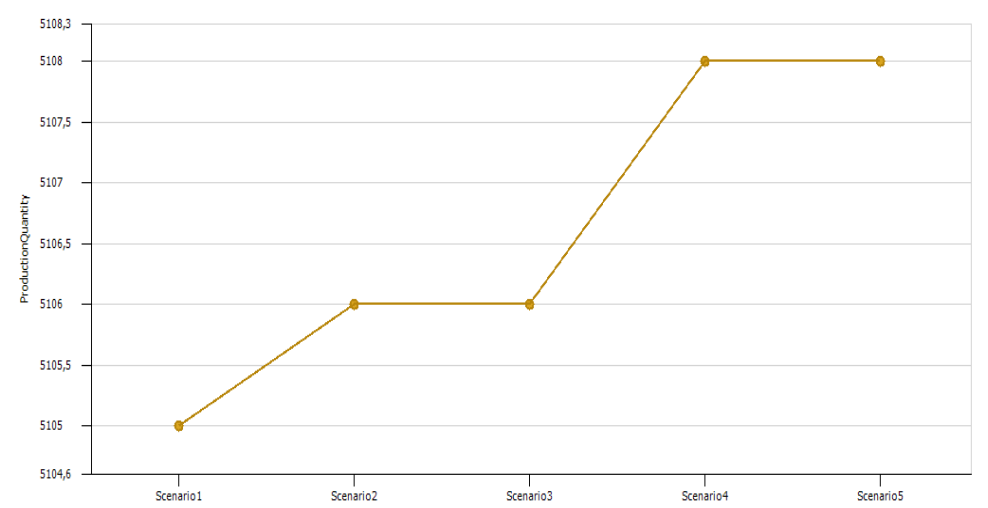

Figure 9. Production quantity due to sub-scenarios in Scenario A

Scenario B analysis: In this case, while the operation time of marking-cutting activity is reducing, the operation times of edge sweeping and grinding activities remain constant. Figures 10 and 11 show the simulation results for Scenario B. In this scenario, operation time for marking and cutting activities is reducing from 6 minutes to 2 minutes. By doing this, it is aimed to determine the effects of changing of operation time of marking and cutting activity on production quantity. In this scenario, there are 5 sub-scenarios (Scenario1 to Scenario 5) and Figure 10 explains their definitions.

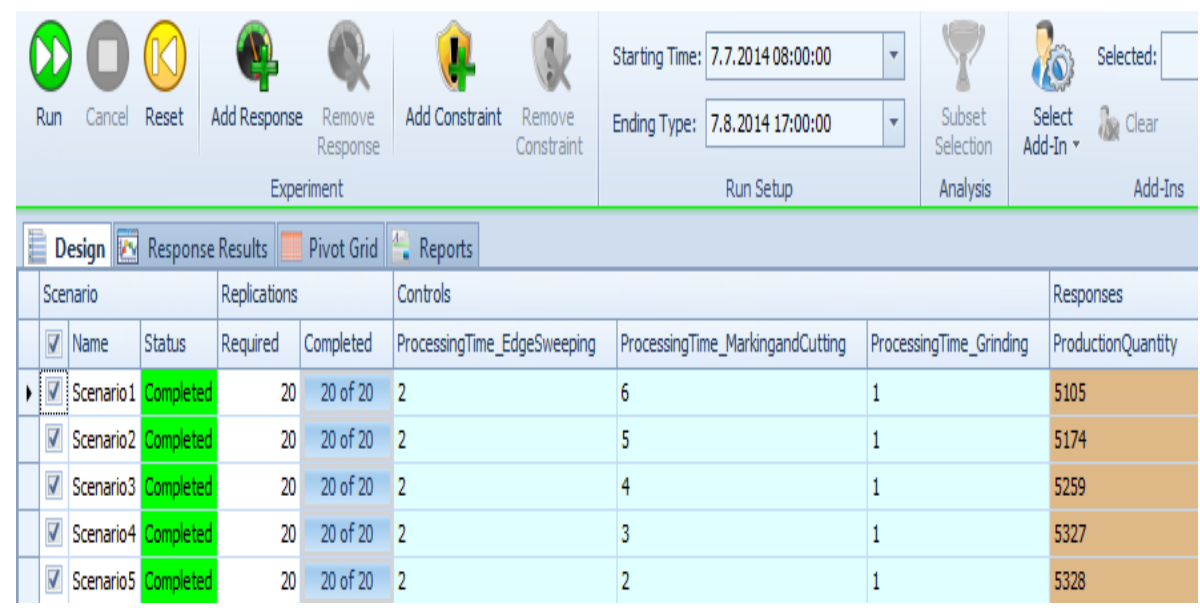

Figure 10. Simulation results based on Scenario B 
M. Özkök / Investigation of Single Section Part Fabrication in Shipbuilding by Utilizing Simulation Environment

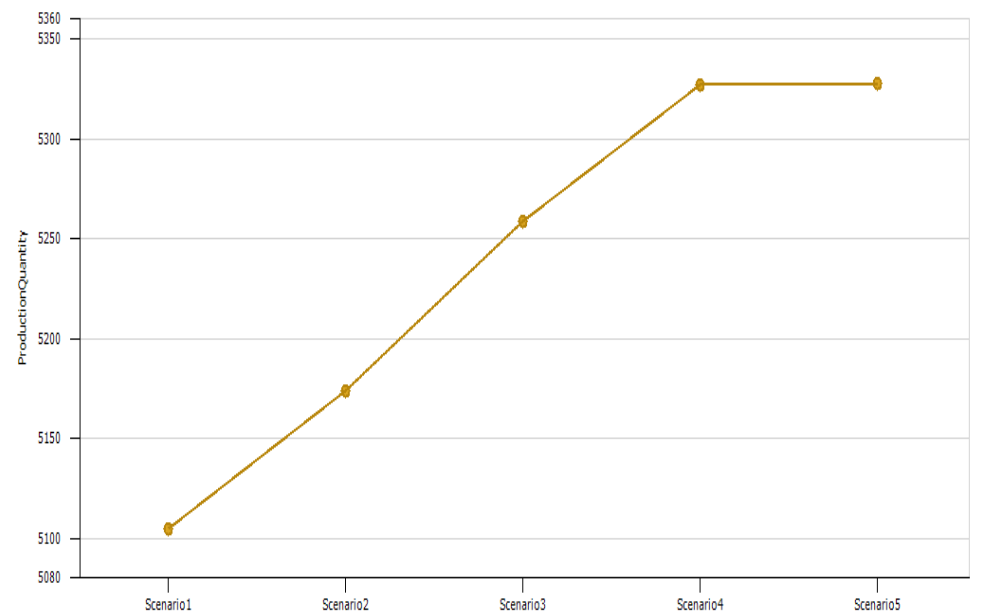

Figure 11. Production quantity due to sub-scenarios in Scenario B

Scenario C analysis: In this case, while the operation time of grinding activity is reducing, the operation times of edge sweeping and marking and cutting activities remain constant. Figures 12 and 13 show the simulation results for Scenario C. In this scenario, operation time of grinding activity is reducing from 1 minutes to 0.4 minutes. By doing this, it is aimed to determine the effects of changing of operation time of grinding activity on production quantity. In Scenario $\mathrm{C}$, number of 4 subscenarios are emerged. For example, in Scenario 3, the operation durations of edge sweeping, marking-cutting and grinding are 2, 6 and 0.6 minutes, respectively.

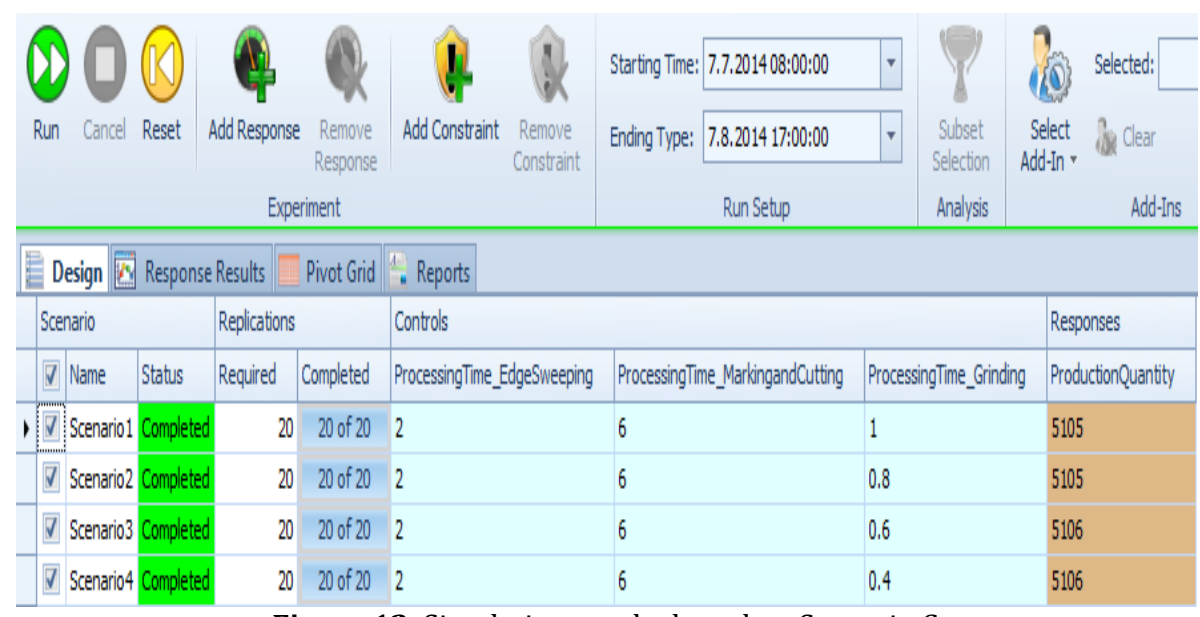

Figure 12. Simulation results based on Scenario C 


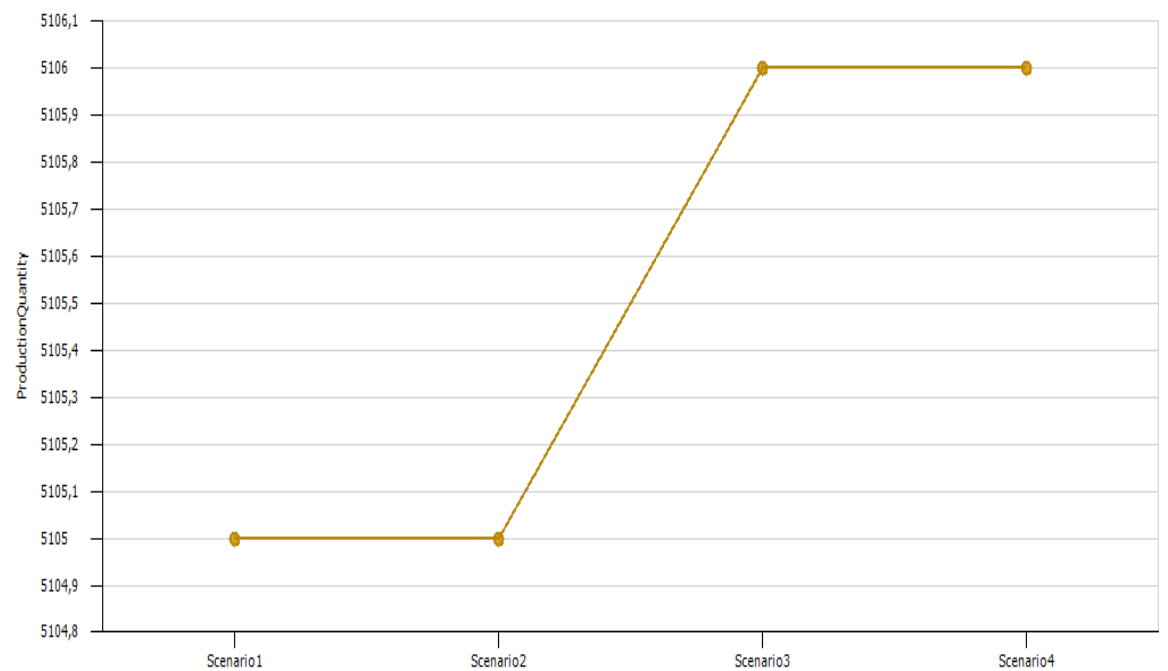

Figure 13. Production quantity due to sub-scenarios in Scenario C

\section{Results}

Figures 8 and 9 demonstrate the simulation results obtained from Scenario A. In this scenario, the processing time of edge sweeping was reduced from 2 minutes to 1.2 minutes while the others (marking-cutting and grinding activities) remained constant. In Scenario 2 (processing time of edge sweeping is 1.8 minutes), the production quantity of profile cutting work unit 5106 that means only an enhancement of 1 profile in throughput. For 1.4 and 1.2 minutes (Scenario 4 and $5)$, the production quantity is 5108 . So, it can be concluded from these results that there is no change in production quantity value when the processing time of edge sweeping is reduced.

In the same way, Figures 10 and 11 show the simulation results achieved from Scenario B and the processing time of mar-king-cutting activity was reduced from 6 minutes to 2 minutes in this scenario. Accordingly, the production quantity of profile cutting work unit increased while other activities (Edge sweeping and grinding) were constant. When the processing time of marking-cutting activity was 6 minutes, the production quantity value was 5105. If the processing time of marking-cutting activity is 2 minutes, the production quantity value reaches 5328. That means, there is an enhancement in production quantity, approximately $4 \%$.

According to Figures 12 and 13 presenting the simulation results of Scenario $\mathrm{C}$, that the processing time of grinding activity was reduced from 1 minutes to 0.8 minutes had no change in the production quantity and after 0.8 minutes, the production quantity increased only number of 1 profile while it remained constant afterwards. Therefore, it can be said that there is no change in production quantity value when the processing time of grinding activity is reduced while the other activities (mar-king-cutting and edge sweeping) are constant. This case can be clearly seen from Table 5 . 
Table 5. Results of scenarios

\begin{tabular}{|l|l|l|l|l|l|}
\hline Scenario no & $\begin{array}{l}\text { Time for } \\
\text { edge } \\
\text { sweeping } \\
\text { (min.) }\end{array}$ & $\begin{array}{l}\text { Time for } \\
\text { marking-cutting } \\
\text { (min.) }\end{array}$ & $\begin{array}{l}\text { Time for } \\
\text { grinding } \\
\text { (min.) }\end{array}$ & $\begin{array}{l}\text { Production } \\
\text { quantity }\end{array}$ & $\begin{array}{l}\text { Improvement rate } \\
(\%)\end{array}$ \\
\hline Scenario A & 1.2 & 6 & 1 & 5108 & 0.06 \\
\hline Scenario B & 2 & 2 & 1 & 5328 & 4.37 \\
\hline Scenario C & 2 & 6 & 0.4 & 5106 & 0.02 \\
\hline
\end{tabular}

\section{Discussions and Conclusions}

In this study, profile cutting activities were considered and these activities were modeled in SIMIO environment and various scenarios were applied on simulation model. Consequently, parameters increasing number of profiles that have specific dimensions were determined. As a result, it was found that the improvements in the duration of the marking-cutting activities increased the profile production quantity while the improvements in the durations of edgesweeping and grinding activities had very little effect on production quantity. Therefore, in order to increase the production quantity at profile cutting work unit, the improvements on marking-cutting activities must be performed. In the case of improvement on marking and cutting activities in profile cutting work unit, production quantity of profile is able to be increased to around $4.5 \%$. On the other hand, the improvements on edge sweeping and grinding activities may cause to increase the throughput of profile cutting work unit as $0.06 \%$ and $0.02 \%$, respectively. Consequently, the shipyard should perform the improvements on marking-cutting activities in order to enhance the profile production quantity.

\section{References}

[1] Xu, J., Huang, E., Chen, C.H., Lee, L.H. 2015. Simulation Optimization: A Review and Exploration in the New Era of Cloud Computing and Big Data, Asia-Pacific Journal of
Operational Research, Vol. 32, No. 3, p. 1-34.

[2] Kelton, D., Smith, J.S., Sturrock, D.T. 2011.Simio and Simulation: Modeling, Analysis, Applications, Sewickley PA, E-book Ed., November 30, p.3.

[3] Song, Y.J., Lee, D.K., Woo, J.H., Shin, J.G. 2010. System Development and Applications of a Shipyard Layout Design Framework, Journal of Ship Production and Design, Vol. 26, No. 2, , p. 144-154.

[4] McLean, C., Shao, G. 2001. Simulation of Shipbuilding Operations, Proceedings of the 2001 Winter Simulation Conference, Arlington, USA, p. 870876.

[5] Shin, J.G., Lee, K.K., Woo, J.H., Kim, W.D., Lee, J.H., Kim, S.H., Park, J.Y., Yim, H. A. 2004. Modeling and Simulation of Production Process in Subassembly Lines at a Shipyard, Journal of Ship Production, Vol. 20, No. 2, p. 79-83.

[6] Kim, H., Lee, S.S., Park, J.H., Lee, J.G. A Model for a Simulation-Based Shipbuilding System in a Shipyard Manufacturing Process, International Journal of Computer Integrated Manufacturing, Vol. 18, No. 6, p. 427-441.

[7] Lee, K., Shin, J.G., Ryu, C. 2009. Development of Simulation-Based Production Execution System in a Shipyard: A Case Study for a Panel Block Assembly Shop, Production 
Planning \& Control, Vol. 20, No. 8, p. 750-768.

[8] Shin, J.G., Song, Y.J., Lee, D.K., Woo, J.H. 2009. A Concept and Framework for a Shipyard Layout Design Based on Simulation, Journal of Ship Production, Vol. 25, No. 3, p. 126-135.

[9] Yasuhisa, O., Kentaro, H. 2005. Digital Manufacturing of Pipe Unit Assembly, Journal of Ship Production, Vol. 21, No. 3, p. 141145.

[10] Cheng, T.M., Feng, C.W. 2003. An Effective Simulation Mechanism for Construction Operations, Automation in Construction, Vol. 12, p. 227-244.

[11] Shin, J.G., Sohn, S.J. 2000. Simulation-Based Evaluation of Productivity For the Design of an Automated Fabrication Workshop in Shipbuilding, Journal of Ship Production, Vol. 16, No. 1, p. 46-59.

[12] Cha, J.H., Roh, M.I. 2010. Combined Discrete Event and Discrete Time Simulation Framework and Its Application to the Block Erection Process in Shipbuilding, Advances in Engineering Software, Vol. 41, p. 656-665.

[13] Woo, J.H., Song, Y.J., Kang, Y.W., Shin JG. 2010. Development of the Decision-Making System for the Ship Block Logistics Based on the Simulation, Journal of Ship Production and Design, Vol. 26, No. 4, p. 290-300.

[14] Song, Y.J., Woo, J.H., Shin, J.G. 2009. Research on a Simulation-Based Ship Production Support System for Middled-Sized Shipbuilding Companies, International Journal of Naval Architecture and Ocean Engineering, Vol. 1, No. 2, p. 70-77.
[15] Lee, D.K., Shin, J.G., Kim, Y., Jeong, Y.K. 2014. Simulation-Based Work Plan Verification in Shipyards, Journal of Ship Production and Design, Vol. 30, No. 2, p. 49-57.

[16] Kolich, D., Storch, R.L., Fafandjel, N. 2011. Lean Manufacturing in Shipbuilding With Monte Carlo Simulation, International Conference on Computer Applications in Shipbuilding, Vol. 3,Trieste, p. 159-167. 